\title{
Pendidikan Interprofessional dan Kolaborasi Interprofesional
}

Norisca Aliza Putriana*, Yulina Br. Saragih

Departemen Farmasetika dan Teknologi Formulasi, Fakultas Farmasi, Universitas Padjadjaran, Jatinangor 45363

*email: norisca@unpad.ac.id

(Submit 10/1/2020, Revisi 21/1/2020, Diterima 26/1/2020)

\begin{abstract}
Abstrak
Pendidikan inter-profesional (IPE) dan praktik kolaborasi interprofesional (IPCP) adalah konsep yang terpisah namun terkait. Salah satu maksud dari IPE adalah bahwa para siswa/mahasiswa dari berbagai profesi kesehatan berlatih sampai tingkat penuh dalam pendidikan dan pelatihan mereka dan, dalam prosesnya, mengeksplorasi batasan dari praktik mereka. Pada saat yang sama, mereka belajar bagaimana memiliki hubungan interprofessional yang efektif melalui berbagi keterampilan dan pengetahuan kolaboratif. IPE terjadi ketika dua atau lebih profesi kesehatan belajar bersama, belajar dari profesi kesehatan lain, dan mempelajari peran masing-masing profesi kesehatan untuk meningkatkan kemampuan kolaborasi dan kualitas pelayanan kesehatan, Kolaborasi terjadi ketika individu saling menghormati satu sama lain dan profesi satu sama lain dan bersedia berpartisipasi dalam suasana kooperatif. Tujuan IPE adalah praktik kolaborasi antar profesi, dimana melibatkan berbagai profesi dalam pembelajaran tentang bagaimana bekerjasama dengan memberikan pengetahuan, keterampilan dan sikap yang diperlukan untuk berkolaborasi secara efektif. kompetensi IPE terdiri atas empat bagian yaitu pengetahuan, keterampilan, orientasi tim, dan kemampuan tim.
\end{abstract}

Kata kunci : IPE, IPC, Profesi kesehatan

\section{Outline}

- Pendahuluan

- Metode

- Hasil dan Pembahasan

- Kesimpulan

- Daftar Pustaka

\section{Pendahuluan}

IPE dan IPCP adalah konsep yang terpisah namun terkait. Bagi profesional kesehatan, belajar keterampilan untuk bekerja secara efektif pada tim IPCP paling baik diperoleh melalui IPE, di mana siswa dari dua atau lebih profesi kesehatan belajar bersama, sehingga mereka dapat memberikan perawatan berbasis pasien yang kolaboratif, aman, bermutu tinggi, mudah diakses. 
Salah satu maksud dari IPE adalah bahwa para siswa/mahasiswa dari berbagai profesi kesehatan berlatih sampai tingkat penuh dalam pendidikan dan pelatihan mereka dan, dalam prosesnya, mengeksplorasi batasan dari praktik mereka. Pada saat yang sama, mereka belajar bagaimana memiliki hubungan interprofessional yang efektif melalui berbagi keterampilan dan pengetahuan kolaboratif. Unsur praktik kolaboratif meliputi tanggung jawab, akuntabilitas, koordinasi, komunikasi, kerjasama, ketegasan, otonomi, saling percaya, dan rasa hormat (Sullivan, 2015).

Centre for the Advancement of Interprofessional Education (CAIPE, 2006) menyebutkan, IPE terjadi ketika dua atau lebih profesi kesehatan belajar bersama, belajar dari profesi kesehatan lain, dan mempelajari peran masing-masing profesi kesehatan untuk meningkatkan kemampuan kolaborasi dan kualitas pelayanan kesehatan. IPE adalah suatu pelaksanaan pembelajaran yang diikuti oleh dua atau lebih profesi yang berbeda untuk meningkatkan kolaborasi dan kualitas pelayanan dan pelakasanaanya dapat dilakukan dalam semua pembelajaran, baik itu tahap sarjana maupun tahap pendidikan klinik untuk menciptakan tenaga kesehatan yang profesional (Lorente, 2006). IPE adalah metode pembelajaran yang interaktif, berbasis kelompok, yang dilakukan dengan menciptakan suasana belajar berkolaborasi untuk mewujudkan praktik yang berkolaborasi, dan juga untuk menyampaikan pemahaman mengenai interpersonal, kelompok, organisasi dan hubungan antar organisasi sebagai proses profesionalisasi (Pittilo, 1998).

Interprofessional Collaboration(IPC) adalah proses dalam mengembangkan dan mempertahankan hubungan kerja yang efektif antara pelajar, praktisi, pasien/ klien/ keluarga serta masyarakat untuk mengoptimalkan pelayanan kesehatan (D'Amour, 2005). Tujuan penulisan artikel ini yaitu untuk mengetahui gambaran pelaksanaan IPE dan IPC untuk memiliki hubungan interprofesional yang efektif melalui berbagi keterampilan dan pengetahuan kolaboratif.

\section{Metode}

Dalam review ini menggunakan berbagai jurnal penelitian yang telah didokumentasikan dan telah di terbitkan baik secara nasional maupun internasional dari 10 tahun terakhir ini, mengenai berbagai macam metode yang digunakan dalam pelaksanaan interprofesional collaboration dan interprofesional education (2006-2016). Jurnal penelitian diutamakan jurnal internasional yang telah terakreditasi. Pencarian data yang digunakan adalah memasukkan kata kunci yang relevan dengan jurnal yang diinginkan kemudian memasukakn rentang tahun dari 2006-2016, dan sebagian besar mensitasi dari beberapa jurnal yang diinginkan. Jumlah studi yang digunakan dalam review jurnal ini sebanyak 13 jurnal.

\section{Hasil dan Pembahasan}

IPCP melibatkan lebih dari sekadar penyedia layanan kesehatan yang berbeda yang menerapkan keterampilan dan pengetahuan unik mereka untuk pengelolaan pasien. Kolaborasi terjadi ketika individu saling menghormati satu sama lain dan profesi satu sama lain dan bersedia berpartisipasi dalam suasana kooperatif (Stone, 2009). 
Tujuan IPE adalah praktik kolaborasi antar profesi, dimana melibatkan berbagai profesi dalam pembelajaran tentang bagaimana bekerjasama dengan memberikan pengetahuan, keterampilan dan sikap yang diperlukan untuk berkolaborasi secara efektif (Vangen, 2003). Implementasi IPE di bidang kesehatan dilaksanakan kepada mahasiswa dengan tujuan untuk menanamkan kompetensi-kompetensi IPE sejak dini dengan retensi bertahap, sehingga ketika mahasiswa berada di lapangan diharapkan dapat mengutamakan keselamatan pasien dan peningkatan kualitas pelayanan kesehatan bersama profesi kesehatan yang lain (Kumar, 1996).

Framework for Action on Interprofessional Education \& Collaborative Practice, WHO (2010) menjelaskan IPE berpotensi menghasilkan berbagai manfaat dalam beberapa aspek yaitu kerjasama tim meliputi mampu untuk menjadi pemimpin tim dan anggota tim, mengetahui hambatan untuk kerja sama tim; peran dan tanggung jawab meliputi pemahaman peran sendiri, tanggung jawab dan keahlian, dan orang-orang dari jenis petugas kesehatan lain; komunikasi meliputi pengekspresikan pendapat seseorang kompeten untuk rekan, mendengarkan anggota tim; belajar dan refleksi kritis meliputi cermin kritis pada hubungan sendiri dalam tim, mentransfer IPE untuk pengaturan kerja; hubungan dengan pasien, dan mengakui kebutuhan pasien meliputi bekerja sama dalam kepentingan terbaik dari pasien, terlibat dengan pasien, keluarga mereka, penjaga dan masyarakat sebagai mitra dalam manajemen perawatan; praktek etis meliputi pemahaman pandangan stereotip dari petugas kesehatan lain yang dimiliki oleh diri dan orang lain, mengakui bahwa setiap tenaga kesehatan memiliki pandangan yang sama-sama sah dan penting (WHO, 2010).

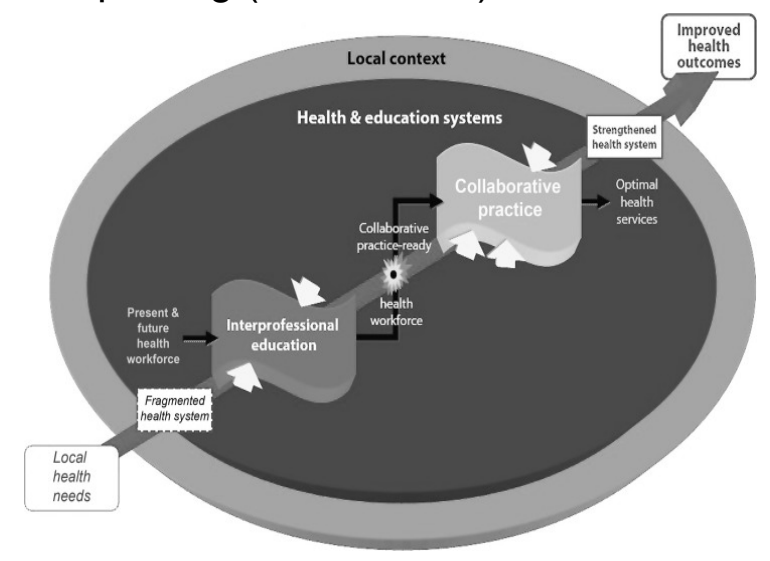

Gambar 1. Kompetensi kolaborasi (Bridges, 2011)

Bridges menjabarkan kompetensi kolaborasi, yaitu:

1) memahami peran, tanggung jawab dan kompetensi profesi lain dengan jelas,

2) bekerja dengan profesi lain untuk memecahkan konflik dalam memutuskan perawatan dan pengobatan pasien,

3) bekerja dengan profesi lain untuk mengkaji, merencanakan, dan memantau perawatan pasien,

4) menoleransi perbedaan, kesalahpahaman dan kekurangan profesi lain,

5) memfasilitasi pertemuan interprofessional, dan

6) memasuki hubungan saling tergantung dengan profesi kesehatan lain. 
ACCP 2009 membagi kompetensi untuk IPE terdiri atas empat bagian yaitu pengetahuan, keterampilan, orientasi tim, dan kemampuan tim. Diane (2011) menyebutkan bahwa penilaian hasil dari pengalaman pembelajaran IPE ini dapat dilihat melalui pemahaman tentang sikap tenaga kesehatan terhadap kolaborasi tim kesehatan dan masing-masing tenaga kesehatan mengerti peran masing-masing tenaga kesehatan merupakan tolak ukur dalam efektifitas educational interventions.

Heinemann et al. (Hyer et al., 2000) merupakan penemu skala Attitudes Toward Health Care Teams yang mana skala ini bertujuan dalam melihat sikap, perspektif, opini terhadap kolaborasi dalam tim kesehatan. Skala memiliki 20 pernyataan yaitu 14 pernyataan untuk kualitas pelayanan kesehatan yang diberikan dan dan 6 pernyataan menilai pemahaman tentang peran masing-masing tenaga kesehatan. Dengan mengacu melalui 14 pernyataan skala ini dapat dilakukan penilaian persepsi pasien dan masyarakat terhadap kualitas pelayanan yang diberikan tim kesehatan dengan kolaborasi berdasarkan IPE (Diane, 2011).

\section{Kesimpulan}

IPE adalah praktik kolaborasi antar profesi, dimana melibatkan berbagai profesi dalam pembelajaran tentang bagaimana bekerjasama dengan memberikan pengetahuan, keterampilan dan sikap yang diperlukan untuk berkolaborasi secara efektif.

\section{Daftar Pustaka}

American College of Clinical Pharmacy. 2009. Interprofessional Education: Principles and Application, A Framework for Clinical Pharmacy. Pharmacotherapy 29(3):14164.

Bridges DR, Davidson RA, Odegard PS, Maki IV, Tomkowiak J.Interprofessional collaboration: three best practice models of interprofessional education. Med Educ Online. 2011.

CAIPE (UK Center for the Advancement of Interprofessional Education). 2006. CAIPE Reissues Its Statement of The Definition and Principles of Interprofessional Education. CAIPE Bulletin 26. Diakses pada tanggal 19 November 2017.

D'Amour D, Ferrada-Videla M. San Martin Rodriguez L, Beaulieu MD. The conceptual basis for interprofessional collaboration: core concepts and theoretical frameworks. J Interprof Care. 2005;((suppl 1)):116-131.

Diane R. Bridges, Richard A. Davidson, Peggy Soule Odegard, Plan V. Maki, nd John Tomkowiak. Interprofessional Collaboration: Three Best Practice Models Of Interprofessional Education. Med Educ Online. 2011

Interprofessional Education Collaborative (IPEC).2011. Core competencies for interprofessional collaborative practice: Report of an expert panel. Washington,D.C.: Interprofessional Education Collaborative. 
Kumar K, van Dissel HG. Sustainable collaboration: managing conflict in interorganizational systems. Manag Inf Syst Q. 1996;20(3):279-300.

Lee, R. 2009. Interprofessional Education:Principles and Application. Pharmacotherapy 29 (3):145-164.

Lorente M., Hogg G., Ker J. 2006. The Challenges of Initiating a Multi-professional Clinical Skills Project. Journal of Interprofessional Care 20(3):290-301.

Pittilo, R.M., Ross, F.M. 1998. Policies for Interprofessional Education: Current Trends in the UK. Education for Health 11(3):285-295.

Sullivan. Mary, Kiovsky. Richard, J. Mason, Diana, Cordelia LMSW; Dukes, Carissa. Interprofessional Collaboration and Education. AJN The American Journal of Nursing: March 2015 - Volume 115 - Issue 3 - p 47-54

Stone J. interprofessional Collaborative Practice:Definitions and Terminology. Canberra: Australian Capital Territory Health; 2009.

Vangen S, Huxham C. Nurturing collaborative relations: building trust in interorganizational collaboration. J Appl Behav Sci. 2003;39:5-31.

World Health Organization. Framework for Action on Interprofessional Education and Collaborative Practice. Geneva: World Health Organization; 2010. 